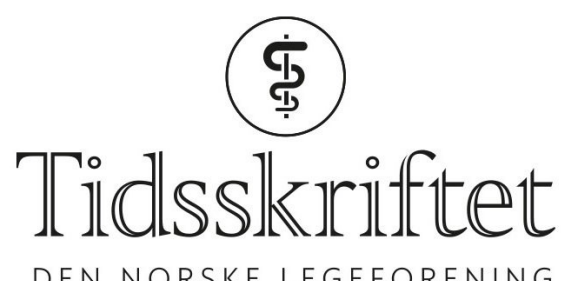

DEN NORSKE LEGEFORENING

\title{
K.Å. Salvesen svarer
}

KOMMENTAR

\section{KJELL ÅSMUND BLIX SALVESEN}

E-post: pepes@ntnu.no

Kjell Åsmund Blix Salvesen er klinikksjef og professor ved Norges teknisk-naturvitenskapelige universitet.

Ingen oppgitte interessekonflikter.

B. Hofmann svarer K.Å. Salvesen i et innlegg som du kan lese på våre nettsider.

Bjørn Hofmann er en debattglad professor som bruker enhver anledning til å skrive kronikker og leserinnlegg mot prenatal diagnostikk og tidlig ultralyd.

I dette innlegget argumenterer han mot bruken av ikke-invasiv prenatal testing i Norge. Han skriver: «Ved innføringen av en så banebrytende teknologi som den aktuelle blodprøven, er det derfor gode grunner til å tenke seg godt om».

I denne saken har Bioteknologinemnda, Beslutningsforum, Helse- og omsorgsdepartementet og Helsedirektoratet tenkt seg godt om. Det er ingen uenighet om innføring av ikke-invasiv prenatal testing, slik metoden er foreslått brukt i Norge. Det blir ikke flere kvinner som får tilbud om prenatal diagnostikk. Metoden skal ikke brukes til å samle «informasjon om alle arveegenskapene til et foster før grensen til selvbestemt abort». Metoden skal erstatte fostervannsprøve og morkakeprøve hos kvinner som har fått påvist $\emptyset \mathrm{kt}$ risiko for trisomi etter kombinert ultralyd og blodprøve (KUB-test). Hvis Hofmann mener dette er problematisk, vil jeg invitere ham til en veiledningssamtale med en gravid kvinne som har fått påvist $ø$ kt risiko for trisomi etter KUB-test. Valget mellom en nål i magen med abortrisiko rundt 1 \% eller en nål i armen med abortrisiko på o \%, er for de aller fleste svært enkelt.

Publisert: 17. april 2018. Tidsskr Nor Legeforen. DOI: 10.4045/tidsskr.18.0236

(C) Tidsskrift for Den norske legeforening 2020. Lastet ned fra tidsskriftet.no 